\title{
A Cosmic Dimension: C. S. Lewis’s Engagement with the Politics of Power and the Challenge of Jesus
}

\begin{abstract}
Brenda Adam
James Cook University

This paper focuses on some literary expressions of the role of faith in our engagement with things political from the pen of C. S. Lewis, whose writings are distinguished by a combination of intellectual force and imaginative flair. In an increasingly secular climate, he sought to bring God back into the equation, and it is not surprising to find some current issues addressed within his imaginative representations of a vibrant spiritual reality. His ideas and ideology are inextricably linked to his Christian faith. Several critical essays reflect his interest in both theology and political issues including: the ethical use of technology, civil liberties, ecology, pacifism, and animal rights. This material forms the layers of his science-fiction trilogy which includes themes of spiritual warfare, factions, faith, and a fairy tale ending. His theology was not confined to the disciplines of a particular school of thought and his approach to things political follows no party line. His critical essays and stories are concerned with the practicalities of life, but are never reduced to a merely social gospel; they always have a cosmic dimension.

Keywords: faith, politics, power, Christianity, ethics, apologetics, imagination
\end{abstract}

For the things which are seen are temporal; but the things which are not seen are eternal.

(2 Corinthians 4: 18)

Religion and politics make a potent mix, more often associated with heat than light, but they are important topics for those serious about being "salt and light" in the community. This paper focuses on some literary expressions of the role of faith in our engagement with political issues from the pen of C. S. Lewis; renowned scholar, author, and innovative communicator of theological concepts to lay people. His writings in diverse genres are characteristically distinguished by a fusion of reason and imagination, the concrete with the theoretical, the natural with the supernatural, and his arguments are still a much valued contribution to current debate. He believes the Bible to be a sacred book composed through human agency and his certainty about eternal realities anticipates a postmodern flexibility of thinking. His theology is not confined to the disciplines of a particular school of thought, and, likewise, his comments on political matters follow no party line. Material drawn from his critical texts comments on civil liberty, gender issues, ecology, pacifism, animal rights, and the ethical use of technology. These are themes which also appear in his multi-layered science-fiction trilogy with its themes of spiritual warfare, factions, faith, and a fairy tale ending. In an increasingly secular climate, he

Brenda Adam, Ph.D. student, College of Arts, Society and Education, James Cook University, Australia; main research field: Literature.

Paper has been presented by Brenda Adam at the 2014 Biennial Conference in Philosophy, Religion, and Culture on the topic of "Faith and the Political." 
seeks to bring God back into the equation, and it is not surprising to find some current issues addressed within his imaginative representations of a vibrant spiritual reality. His stories are concerned with the practicalities of life, but are never reduced to a merely social gospel; they always have a cosmic dimension.

His apologetic writings on the subject of faith demonstrate an understanding of the depth of meaning found in the Hebrew terms, and in the Latin and Greek translations: fides and pistis. Biblical references to "faith" and "faithfulness" are interchangeable, communicating the dual aspects of a relationship between subjective, strong conviction and a trustworthy object. In Christian armor imagery, faith is a shield. Lewis devotes a chapter in Mere Christianity to the complexities of the abstract and practical implications of the concept, stressing our need to train the habit of faith due to the very human side of the relationship which is though initially based on a rational response is vulnerable to our fluctuating moods and circumstances. It is easy to relate to his following words: “... faith is a necessary virtue: unless you teach your moods 'where to get off,' you can never be either a sound Christian or even a sound atheist, but a creature dithering to and fro, with its beliefs dependent on the weather and the state of its digestion" (122).

Lewis defends faith and the supernatural during the ascendency of modernism, an age summarized by contemporary theologian N. T. Wright as characterized by individuality, "the all-powerful 'I,'” and the "industrial economy" which transformed landscape and culture (The Challenge of Jesus, 151). Wright claims that "Modernity stands condemned of building a tower of Babel" (152). He uses the same scriptural precedent as Lewis does in his space trilogy to link the exploitation of people and natural resources with the lust for power and unhealthy pride. The future predicament envisaged by Lewis of life without objective truth or values is in part identified by Wright with the experience of living now "at the overlap of several huge cultural waves" (151). This is expressed as the yearning to be closer to nature, rooted in agriculture yet born along by the current of the microchip economy: "We live in a cultural, economic, moral and even religious hypermarket" (152). This current climate of relativism does, however, in some sense allow a hearing to the voice of religious faith in any debate, because secular or atheistic statements must also be held to be subjective opinions.

Lewis's ideas have been variously termed as "conservative," "liberal," "green," or "socialist" but his political views and his hope for the human species are inextricably linked to his Christian faith. His political stance could be summed up as one of resistance to any form of authoritarianism and the nefarious extremes of ideologically driven causes. In an article on Lewis as a "Political Thinker" (posted in the Independent Institute, July 15, 1995), John G. West suggests that: "By avoiding the partisan strife of his own time, he (Lewis) was able to articulate enduring political standards for all time." The only political label Lewis owns is as a "democrat," in the sense that he believed no individual or group could be trusted with uncontrolled power over others (“A Reply to Professor Haldane," Of This and Other Worlds, 105). In a letter written during WW II (17 January 1940), he suggests that, "Fascism and Communism, like all other evils, are potent because of the good they contain or imitate...” (Letters of C. S. Lewis, 176). It is a comment that recognizes the complexities of political agendas, the paradoxes of human nature, and our national and personal failings. In Mere Christianity, he reminds readers of the divine mission statement for the Church universal, the call to make disciples, restoring individuals to relationship with their creator, and in the process influencing society for the better. These comments should in no way be interpreted as a vote for any type of ecclesiastical authoritarianism as we see from Lewis's comment in "Is Progress Possible” (1958): "I detest theocracy. For every Government consists of mere men and is, strictly viewed, a makeshift; if it adds to its commands 'Thus saith the Lord;' it lies, and lies dangerously” (God in the Dock, 315). 
He extends this cautionary wisdom beyond leaders to all communicants because, as he points out in "Meditation on the Third Commandment” (1941): "The danger of mistaking our merely natural, though perhaps legitimate, enthusiasms for holy zeal, is always great” (God in the Dock, 198). This thought is behind his opposition to any attempt to form a Christian political party. He believes it wiser to encourage the presence of a Christian conscience in the community, an influence spread across the political divide. This non-partisan spirit is borne out by Lewis's refusal to make donations to any political party, although he was extraordinarily generous to charitable causes. He does, however, encourage active participation in articulating a Christian voice. This would involve "pestering" members of parliament with letters on specific issues (GID, 199), a pestering that should combine the wisdom of serpents and the peacefulness of doves, in accordance with the Apostle Luke's counsel (Luke 12: 14). Lewis's challenge is to the whole household of faith not just to clergy. He points out that when people expect "the Church" to give the lead in social matters, the burden rests on the "whole body of practicing believers." This is expressed most clearly in the closing line: "He who converts his neighbor has performed the most practical Christian political act of all” (GID, 199).

Lewis lived at a time when technology and the sciences were increasingly viewed as the great hope of humankind, the potential remedy for all ills and the assurance of ultimate survival of our species in a hostile universe. Lewis felt compelled to draw attention to the likely outcomes and cost of a secular faith which denied God as a first cause and put complete trust in the ability of human intelligence to subdue the forces of nature: “... There neither is nor can be any simple increase of power on Man's side. Each new power won by man is a power over man as well. Each advance leaves him weaker as well as stronger. In every victory, besides being the general who triumphs, he is also the prisoner who follows the triumphal car” (AOM, 35-36).

This is a caution about the manipulation and misuse of power, not an anti-science statement. In an informal session of, "Answers to Questions on Christianity” (1944), he makes the following comment regarding Christianity's approach to scientific advancement: “... as a general rule, it is in favor of all knowledge and all that will help the human race in any way" (GID, 57). In a chapter entitled "Social Morality" in Mere Christianity, he makes it clear that the Christian faith "was never intended to replace or supersede the ordinary human arts and sciences" (75). But when embraced, it can be a civilizing and inspirational force in society. As Lewis points out, there are no detailed instructions on how to obey "the golden rule of the New Testament:" "Do as you would be done by," and when we are told to feed the hungry there are no lessons in cookery. The principles are universal— “meant for all men at all times” (75). Lewis’s perspective recognizes the need for prayerful adaptation and human initiative in particular times and situations. On an individual level, he emphasizes that our own personal striving for material progress in life should be in a right spirit, driven not by selfish dreams of status or power, but by the pursuit of excellence and the common good.

In Mere Christianity, he looks into the practicalities of being salt and light in society which involves applying Christian principles to all aspects of life. Lewis cites the great commission of Jesus to his followers, stressing that the call is to clergy and laity, and includes "economists, statesmen, trade unionists, educators, novelists, and dramatists” (76). He re-iterates the primary tasks of State and Church which, if neglected, render other "trappings" a waste of time: "The State exists simply to promote and protect the ordinary happiness of human beings in this world... In the same way, the Church exists for nothing else but to draw men into Christ” (167).

"Happiness” here equates to the Greek concept of "eudaimonia” or the philosopher Charles Taylor’s term, "human flourishing," meaning an objective, ultimate good, more than a subjective sense of pleasure. Lewis 
advocates order and leadership rather than anarchy in Church, State, educational institutions, workplace, or home but resists any form of tyranny. The following passage from his paper "Membership” (1945) comments on domestic failures:

The authority of father and husband has been rightly abolished on the legal plane, not because this authority is in itself bad (on the contrary, it is, I hold, divine in origin), but because fathers and husbands are bad... Even the authority of man over beast has had to be interfered with because it is constantly abused. (The Weight of Glory, 168-9)

In principal, he embraces both hierarchy and egalitarianism as elements of the cosmic pattern, but he counsels against policies that attempt to artificially level everyone, because this can discourage the pursuit of excellence. In a church context, his paper invokes the Pauline principle of the Church as a "body" of Christ, composed of diverse members, an organic unity functioning in a harmony of differing gifts. This is something that Lewis had to learn, as we see from this admission in “Answers to Questions on Christianity:” I thought I could do it on my own, by retiring to my rooms and reading theology, and I wouldn't go to the churches and Gospel halls... But as I went on I saw the merit of it. I came up against different people of quite different outlooks and different education, and then gradually my conceit just began peeling off" (GID, 61-62).

The paper, "Is Progress Possible," shows that Lewis is mindful of the complexities involved in balancing human needs with responsible government: the necessity of the populace sacrificing some independence and privacy in return for security and the restraint of evil: "We have on one hand a desperate need, hunger, sickness, and the dread of war. We have, on the other, the conception of something that might meet it: omnicompetent global technocracy" (GID, 315-6). Having lived through the devastation of two world wars and the collapse of socialist regimes, he witnessed Hitler's use of mechanization to dominate nations, and his preparedness to commit genocide in the name of a secular ideological cause. Lewis notes that history has shown that power corrupts. Rulers or governments once trusted to protect citizens have assumed control over all aspects of their lives, creating dependency and demanding compliance to policies designed to promote the State's agenda: "Is there any possibility of getting the super Welfare State's honey and avoiding the sting?” he asks. Lewis is realistic about the limitations of human agencies and projects:

We shall grow able to cure, and to produce, more diseases... to alleviate, and to inflict, more pains, to husband, or to waste the resources of the planet more extensively... My guess is we shall do both, mending one thing and marring another, removing old miseries and producing new ones, safeguarding ourselves here and endangering ourselves there. (GID, 312)

It is an argument for marrying faith with the political; a reiteration of his belief that our natural aims and efforts need to be "baptized" to make real progress.

The essay, "Christianity and Culture," (1940) applies the same standard to the aesthetic and intellectual activities of life. Influential critical theorists at the time were espousing the idea that education in approved literature and exposure to "good taste" in the arts could have the same sanctifying effect on human character and behavior as traditional religious beliefs. Lewis is challenged by this view to examine how "culture" is valued in ancient writings, Turning First to the New Testament, he finds a diversity of passages which, read in context, provide a counsel of behavioral checks and balances. Some passages exhort the aesthetic and educational value of studying the natural world, but this is tempered by a firm discouragement from confusing culture with spirituality or from valuing it above relationship with the author of life. Overall, he concludes that culture may be a "storehouse" of the best earthly values, a small taste of things spiritual but without any power of "regeneration." The most dominant teaching he finds is against "every kind of superiority" (Christian 
Reflections, 30), and in Mere Christianity he describes pride as "the complete anti-God state of mind" (107). His graphic application of this precept to himself is found in a continuation from a previous quote, when Lewis admits to being convicted of his own social conceit, and snobbery about "inferior" music in popular hymns: "I realized that the hymns, were, nevertheless, being sung with devotion and benefit by an old saint in elastic-side boots in the opposite pew" (GID, 62). The truth dawned on Lewis then that he was not "fit to clean those boots."

Political themes found in the critical and apologetic texts cited appear in dramatized form in Lewis's trilogy of inter-planetary exploration (1938-1945). The science-fiction genre invites "other worldly" dimensions into the discourse. Biblical themes of temptation, rebellion against God, sacrifice, and spiritual warfare are interwoven with pagan mythology in an inter-textual portrayal of power politics. It is not a dystopian work like Orwell's Nineteen Eighty-Four, because Lewis presents an alternative way of life, and a savior in the person of "Ransom," a name that destines the protagonist at some point in the narrative to take on the role of a type of Christ figure. Each story stands on its own but there is a definite progression in the course of events and an intensification of violence. Common threads involve the clash of ideologies, biotechnology, ecology, colonization, pacifism, animal rights, and gender issues. The first novel, Out of the Silent Planet, refers to Earth's corrupted faculties of communication and depicts abuses of power in colonialism. The protagonist Dr. Elwin Ransom (a philologist) is forcibly taken on a mission to the uncorrupted planet Malacandra (Mars), where three rational, alien races live together in a harmony of difference under the benign rule of the presiding Oyarsa (a spirit being). Ransom's captors, Devine and Weston, personify the spirit of scientism and the predatory aspects of progress. Devine is a wealthy materialist, hungry for gold and advancement, displaying a very cynical approach to progress, prepared to sacrifice animals and people for experimental purposes. His following statement sounds like a manifesto for anthropocentrism:

I am prepared without flinching to plant the flag of man... to march step by step, superseding, where necessary, the lower forms of life... claiming planet after planet, system after system till our posterity-whatever strange form and yet unguessed mentality they have assumed—dwell in the universe wherever the universe is habitable. (OSP, 155)

Weston epitomizes the man-centered, acquisitive spirit that inspires some futuristic ideas of inter-galactic travel at the time. He is a more complex character with "spiritual" dimensions but as the trilogy demonstrates, "spiritual" does not necessarily equate to "good" because Weston taps into the demonic. An alternative approach is demonstrated by Ransom who eludes his captors and explores the strange, but benign environment as a translator and ethnographer. As a participant observer, he sensitively interacts with the culture, learning the language, studying social structures and the weird flora and fauna of an uncorrupted planet.

The second novel, Perelandra (Venus) reshapes the Genesis story of temptation into a spiritual and ideological battle to save a pristine planet, but the story also confronts the dilemma of physical engagement. Lewis revisits his own first-hand experience and wounding in WWI (he carried shrapnel in his chest for the rest of his life). Through Ransom's consciousness Lewis pictures real troops fighting at the time of writing: "At that moment, far away on Earth... men were at war, and white-faced subalterns and freckled corporals who had but lately begun to shave, stood in horrible gaps or crawled forward in deadly darkness, awaking, like him, to the preposterous truth that all really depended on their actions" (161-2).

The passage argues the horrors of war but is not a vote for pacifism. WWII is a direct consequence of Hitler's predatory ambitions and aggressive policies. In C. S. Lewis on the Final Frontier (2009), Sanford 
Schwartz points out how the war changes the world map, and deduces that: "In setting Ransom's final battle in post-war England, Lewis makes it clear that the ideological issues at stake in the conflict would not disappear with the demise of fascism. Indeed, they are very much with us today" (6).

The final novel, That Hideous Strength, (described by Lewis as a fairy tale for adults) is a departure from interplanetary travel, but depicts the supernatural interaction of ordinary people with mythical figures and angelic beings. The story dramatizes Lewis's defense of truth and absolute values in his apologetic text The Abolition of Man. He concedes that the concerns are not yet a reality, but are not optimistic: "I am doubtful whether history shows us one example of a man, having stepped outside traditional moral values and attained power, has used that power benevolently" ( $A O M, 40)$. The earthbound settings feature a rural community where the haven at St. Anne's is the residence of "good," and Belbury the locus of evil. Lewis claims to use a university setting because that is the one with which he, as an academic, is most familiar, "not because I think fellows of colleges more likely to be thus corrupted than anyone else, but because my own profession is naturally that which I know best” (THS, 7). In his chapter “The Ransom Trilogy,” T. A. Shippey describes Lewis's early account of a college meeting "with its cunningly rigged agenda” as a "gem," born of Lewis's “twenty years' experience of office politics” (The Cambridge Companion to C. S. Lewis, 244). A specific target is the power of "unwritten systems." This subject is covered in more depth in "The Inner Ring," an address by Lewis to a group of young people about to embark on their careers. While acknowledging that exclusive groups can serve a useful purpose (current equivalents might include cyber sites such as LinkedIn, Facebook, or Instagram), he cautions that if the desire to be an initiate, the liking for "secret intimacy" becomes stronger than any moral considerations, then the exclusive environment is capable of making someone who is not yet bad do very bad things (The Weight of Glory, 149-54).

That Hideous Strength dramatizes the importance of both corporate and individual integrity to the moral and political health of society at large. The plot involves environmental concerns and some recognizable cultural and political issues. The National Institute for Co-ordinated Experiments (whose ironic acronym is N.I.C.E) has a massive bureaucracy with 15 highly paid departmental directors, its own legal staff and police. The effects of excessive bureaucracy (a feature of today's society), and the de-humanizing of language are depicted through the protagonist Mark Studdock, whose, "education had the curious effect of making things that he read and wrote more real to him than things he saw... Statistics were the substance” (104). Real people become "vocational groups," "elements," "populations” or “classes.” N.I.C.E. tactics include false propaganda, lies, intimidation, and deliberate stirring up of social unrest. The plans involve selective breeding, sterilization of the unfit, liquidation of backward races, pre-natal education, and direct manipulation of the brain. These procedures were actually being considered by some progressives in Lewis's day for the perfecting of the human race. Shippey claims that many of Lewis's concerns “have proved unnecessary” (CC, 247), but even if this is so, it is not proof that the alarm was unjustified. It is equally possible that the voices of Lewis and other critics of progressive extremism may have tempered the popular enthusiasm for unprincipled, futuristic social engineering. Even a cursory look at current literature on "Transhumanism" indicates the need for vigilance.

The N.I.C.E programs are brutally advanced without compassion for residents, flora, or fauna. The destruction and pollution are not just accidental to the inevitable march of progress but are a deliberate ploy to replace the mud and mess of the organic with the mechanical and virtual. Lewis's fictional protest against "non-moral utilitarianism” relates to his activism in the cause of animal welfare. His essay "Vivisection” (1947) makes this claim: "In justifying cruelty to animals, we put ourselves also at the animal level. We choose the 
jungle and must abide by our choice” (GID, 228). The point is dramatized in the apocalyptic scenes of violence and carnage enacted in the command centre at Belbury when the final act of poetic justice is literally carried out by liberated animals. Lewis's stand attracts the stereotypical label of "crank" applied to protesters like himself. He views this as evidence of a decline in rational argument, resulting in attempts to silence genuine debate by "name calling" and contemptuous dismissal; a tactic increasingly employed today by some political activists and new atheists. One positive sign that the decline in debate is being addressed is the formation in the U.K. of an All Party Parliamentary Group for informal discussions on social issues. When the Archbishop of Canterbury, Justin Welby was recently invited to speak on "The Good Economy" (4 Feb. 2015), he began by announcing his intention to address matters of social justice by speaking of God, creation and Jesus, drawing on scriptural precepts regarding creativity, generosity and sustainability. Like Lewis, he stresses the shared responsibility of the state, the market, the wider society and individuals in the advancement of the common good.

Lewis challenges materialistic worldviews which deny any supernatural dimension to human affairs and exclude theological perspectives from mainstream discourse. His use of the science-fiction genre encourages the visualization of a greater, non-sensory reality. In argument and story form he articulates that faith is both an anchor and an empowering force, just as influential to the health of our future plans and hopes as are political activities. The full meaning of the faith concept has been diminished in popular culture to something nebulous or equivocal. The Christian worldview is sometimes patronized as a private idiosyncrasy of no vital importance, or sometimes castigated as obscurantist or even toxic. Religious faith is labeled "blind," although faith of some kind is involved in the pursuit of knowledge in all disciplines. Lewis's motivation is to present faith not as a delusory coping mechanism but as a path of access between creature and Creator. It is rational and intensely practical-inspirational and important to the organization of ethical social and economic policies, or any other activities of daily life. The last word on the subject I give to the New Testament writer to the Hebrews, who ascribes an equally concrete aspect to the concept by defining faith, defining it as, "the substance of things hoped for, the evidence of things not seen” (Hebrews 11: 1).

\section{Works Cited}

Lewis, C. S. The Abolition of Man (1943). Glasgow: Fount Paperbacks, 1978.

---. “A Reply to Professor Haldane.” Of This and Other Worlds. Ed. Walter Hooper. London: Fount Paperbacks, 1982.

---. God in the Dock. Essays on Theology and Ethics. Ed. Walter Hooper. Grand Rapids: William B. Eerdmans Publishing Company, 1970.

---. Letters of C. S. Lewis. Edited with a Memoir, by W. H. Lewis. London: Geoffrey Bles, 1966.

---. Mere Christianity. London: Fount Paperbacks, 1977.

---. Out of the Silent Planet (1938). London: The Bodley Head, 1971.

---. Perelandra (1943). London: The Bodley Head, 1970.

---. The Weight of Glory and Other Addresses. New York: Harper Collins, 1980.

Schwartz, Sanford. C. S. Lewis on the Final Frontier. Oxford: Oxford UP, 2009.

Shippey, T. A. “The Ransom Trilogy.” The Cambridge Companion to C. S. Lewis. Eds. Robert MacSwain and Michael Ward. Cambridge: Cambridge UP, 2011.

West, John G. Jr. "Finding the Permanent in the Political: C. S. Lewis as a Political Thinker." $<$ www.independent.org/newsroom/article.asp?id=1566>.

Wright, N. T. The Challenge of Jesus. Downers Grove, Illinois: Inter Varsity Press, 1999. 